\title{
Progesterone-binding proteins in plasma of guinea-pigs and other hystricomorph rodents
}

\author{
R. B. Heap, Nicola Ackland and Barbara J. Weir* $†$ \\ A.R.C. Institute of Animal Physiology, Babraham, Cambridge CB2 4AT, ${ }^{*}$ Wellcome Institute of \\ Comparative Physiology, Zoological Society of London, London, NWI 4RY, and *Department \\ of Anatomy, University of Cambridge, Cambridge CB2 $3 D Y, U . K$.
}

\begin{abstract}
Summary. Progesterone-binding plasma proteins (PBPP, progesterone-binding globulin, PBG, and corticosteroid binding globulin, CBG) have been measured in plasma of guinea-pigs, casiragua, cuis, degu and plains viscacha. During pregnancy PBPP increased to reach peak values between Days 20-25 and Days 50-term in guinea-pigs, immediately before parturition in casiragua, and in mid-gestation in cuis, degu and viscacha. The pattern of PBPP concentration during pregnancy was similar to that of plasma progesterone concentration, and the ratio of molar concentration of PBPP and progesterone was greater than 1 in all species. Plasma proteins were separated by chromatography on SP-Sephadex C-50, and from its chromatographic behaviour and progesterone-binding property evidence was obtained for an anionic, high-affinity PBG in the plasma of all the animals studied during gestation: Electrophoretic mobility of SP-Sephadex-purified PBG applied to $7 \%$ polyacrylamide gels differed between species, being highest for casiragua PBG and lowest for guinea-pig PBG. Binding capacities ranged from 0.5 to $4.8 \times 10^{-6} \mathrm{M}$, and association constants from 7.6 to $17.4 \times 10^{8} \mathrm{M}^{-1}$. Ligand specificities differed between species and marked contrasts were found for certain steroid isomers. The average molecular weights measured by gel electrophoresis of PBG under denaturing conditions were similar in cuis, degu and viscacha and close to PBG I of guinea-pigs, while coypu PBG had a molecular weight of about one half, approximately 75000 .

It is concluded that PBG has been adopted in pregnancy as a progesteroneconserving mechanism in this suborder of rodents with long gestation periods relative to maternal body weight. Restricted homologies in the physico-chemical characteristics of PBG from various hystricomorph rodents suggest that interspecific differences in structure are considerable.
\end{abstract}

\section{Introduction}

A high-affinity progesterone-binding protein present in plasma of pregnant guinea-pigs is distinguishable from corticosteroid-binding globulin (CGB) by its relative ability to withstand heating at $60^{\circ} \mathrm{C}$ (Heap, 1969). Evidence for a mechanism that reduced the rate of progesterone metabolism during gestation in this animal (Heap \& Deanesly, 1967) was substantiated by direct measurement of the kinetics of progesterone metabolism (Illingworth, Heap \& Perry, 1970) and the plasma concentration of high-affinity binding protein (Heap \& Illingworth, 1974). Thus, the metabolic clearance rate of progesterone in guinea-pigs declined by about $90 \%$, progesterone-

$\dagger$ Present address: Journal of Reproduction \& Fertility, 22 Newmarket Road, Cambridge CB5 8DT, U.K. 
binding protein increased, and plasma progesterone concentration rose about 100 -fold between Days 15 and 25 post coitum (p.c.). Diamond, Rust \& Westphal (1969) had also found that steroid binding in serum rose appreciably for progesterone and testosterone, and to a lesser extent for cortisol, with highest values occurring in late gestation. Subsequent work resulted in the isolation of progesterone-binding protein, and in the characterization of its physico-chemical and immunochemical properties (PBP-Milgrom, Atger \& Baulieu, 1970; PBG, progesteronebinding globulin-Burton, Harding, Rust \& Westphal, 1971; Lea, 1973a, b; Milgrom, Allouch, Atger \& Baulieu, 1973; Burton, Harding, Aboul-Hosn, MacLaughlin \& Westphal, 1974; Kontula, Jänne, Rajakoski, Tanhuanpää \& Vihko, 1974; Tan \& Murphy, 1974; Stroupe \& Westphal, 1975; Perrot \& Milgrom, 1978).

Similar high-affinity progesterone-binding proteins have been found in other hystricomorph (caviomorph) rodents (Illingworth, Ackland, Heap \& Weir, 1973; Heap \& Illingworth, 1974), but they were not detected in murine rodents (rat and mouse), or in rabbit, ferret, pig, sheep or woman. The present study was concerned with the time course of PBG production in various hystricomorph rodents in relation to the establishment of the definitive allantochorionic placenta. In addition we have used the single-step purification procedure developed by Stroupe \& Westphal (1975) to examine the binding characteristics, ligand specificity and electrophoretic properties of PBG from different hystricomorph rodents. Sulphopropyl (SP)-Sephadex-purified protein is referred to as PBG after the nomenclature proposed by Burton et al. (1974) since it behaves as an $\alpha$-globulin during electrophoresis; PBPP refers to high-affinity progesteronebinding plasma proteins which include $\mathrm{PBG}$ and $\mathrm{CBG}$, quantitatively the most important forms in guinea-pigs. Data for the pattern of PBPP in cuis and casiragua are taken from a previous paper (Heap \& Illingworth, 1974).

\section{Materials and Methods}

\section{Animals}

Mature female guinea-pigs, weighing 600-1000 g were obtained from the Institute's colony of mixed stock. Pregnancy was dated from the mating when a vaginal plug was found. Coypus (Myocastor coypus), 6-8 kg, were also obtained from the Institute's colony and pregnancy was dated from known matings post partum. Material from other hystricomorph (caviomorph) species, casiragua (Proechimys guairae; 300-400 g), cuis (Galea musteloides, 400-500 g), degu (Octodon degus, 200-300 g) and plains viscacha (Lagostomus maximus, 2.5-4 kg), was provided from breeding colonies (Weir, 1970, 1972, 1973) at the Wellcome Institute of Comparative Physiology and the Department of Anatomy, University of Cambridge. Pregnancy in these animals was dated from known matings or retrospectively from parturition.

\section{Blood samples}

Heparinized blood samples were collected by cardiac puncture under light ether anaesthesia. The blood was centrifuged at $500 \mathrm{~g}$ for $20 \mathrm{~min}$ and the plasma was removed and stored at below $-10^{\circ} \mathrm{C}$ until analysis.

\section{Determination of progesterone-binding proteins $(P B P P)$}

Progesterone binding in plasma was measured by an adsorbent technique using dextran-coated charcoal (DCC, 0.625\% activated charcoal, Sigma, Poole, Dorset, U.K., and $0.0625 \%$ dextran T70, Pharmacia, Uppsala, Sweden) in phosphate-buffered saline, pH $7 \cdot 2$, containing $0.2 \%$ sodium azide (Hopkin \& Williams, Chadwell Heath, Essex, U.K.) and $0 \cdot 1 \%$ gelatin (Fisons, Loughborough, Leics, U.K.) to remove unbound progesterone. Plasma was 
diluted 100-fold in $50 \mathrm{~mm}$-phosphate buffer (pH 7.2) and $1 \mathrm{ml}$ was incubated with increasing amounts of progesterone (Sigma) $(0-4 \mu \mathrm{g})$ and $0.2 \mathrm{kBq}\left[1,2-{ }^{3} \mathrm{H}\right]$ progesterone (sp. act. 1.85 $\mathrm{GBq} / \mu \mathrm{mol}$ : Radiochemical Centre, Amersham, Bucks, U.K.) for $15 \mathrm{~min}$ at $37^{\circ} \mathrm{C}$ and then overnight at $4^{\circ} \mathrm{C}$. Dextran-coated charcoal $(0.2 \mathrm{ml})$ was added and mixed thoroughly. After 10 min incubation the tubes were centrifuged at $600 \mathrm{~g}$ for $15 \mathrm{~min}$. Incubation for $10-20 \mathrm{~min}$ provided an efficient separation of free and protein-bound steroid and under these experimental conditions produced negligible dissociation of steroid-protein complexes. The supernatant, containing the bound progesterone, was decanted into scintillation vials. Scintillation fluid (5 ml $0.4 \%$ dephenyloxazole, Fisons, in toluene) was added and the amount of protein-bound radioactivity was counted in a Packard Tri-Carb spectrometer. The quantities of bound and free steroid were calculated from the total of endogenous and added steroid, and the results were plotted according to the method of Scatchard (1949). The PBG concentration and its association constant were calculated by the method described by Pegg \& Keane (1969).

A single-point method was developed to allow large numbers of samples to be analysed simultaneously for PBG capacity. For each species a plasma sample from a mid-pregnant animal was analysed by the method already described to determine the optimal concentration of progesterone required to ensure saturation of PBG binding sites with minimum interference by low affinity non-specific binding proteins (guinea-pig, $500 \mathrm{ng}$; viscacha, $50 \mathrm{ng}$ ). By this modified procedure $1 \mathrm{ml}$ diluted plasma (1 in 100 dilution, $50 \mathrm{~mm}$-phosphate buffer, $\mathrm{pH} 7 \cdot 2$ ) from a pregnant animal was incubated with the appropriate amount of progesterone and $0.2 \mathrm{kBq}$ $\left[1,2-{ }^{3} \mathrm{H}\right]$ progesterone for $15 \mathrm{~min}$ at $37^{\circ} \mathrm{C}$ followed by $4-24 \mathrm{~h}$ at $4^{\circ} \mathrm{C}$. Bound and unbound progesterone were separated by the method described previously, using dextran-coated charcoal. To eliminate the effect of non-specific binding, a sample from a non-pregnant animal of the same species was analysed simultaneously. The amount of progesterone bound by this sample was subtracted from the total bound by the plasma from the pregnant animal. The capacity of PBPP ( $\mathrm{nmol} / \mathrm{ml}$ plasma) was calculated from the equation: (amount of progesterone bound (pregnant) amount of progesterone bound (non-pregnant)/314) $\times 100$. Since each molecule of progesterone binding protein (PBG and CBG) from guinea-pig plasma contains 1 binding site for progesterone (Milgrom et al., 1973), values for binding capacity of proteins are expressed as PBPP concentration $(\mathrm{nmol} / \mathrm{ml})$. Values obtained by Scatchard and single point analysis respectively were 7.7 and 7.5 (guinea-pig) and 1.54 and 1.4 (viscacha).

\section{Purification of $P B G$}

Blood was collected by cardiac puncture from mid-pregnant animals; plasma was pooled and incubated with $\left[{ }^{3} \mathrm{H}\right.$ ]progesterone $\left(37 \mathrm{kBq}\right.$ per ml plasma) for $30 \mathrm{~min}$ at $37^{\circ} \mathrm{C}$ followed by $30 \mathrm{~min}$ at $60^{\circ} \mathrm{C}$ to denature CBG. After heating a flocculent precipitate usually developed and after showing that it contained negligible radioactivity, the precipitate was removed by centrifugation at $600 \mathrm{~g}$ for $30 \mathrm{~min}$. The supernatant was then applied to a column $(3.5 \times 60 \mathrm{~cm})$ of SP-Sephadex C-50 (Pharmacia) equilibrated with $10 \mathrm{~mm}$-acetate buffer, $\mathrm{pH} 4 \cdot 5$, at $4^{\circ} \mathrm{C}$. The proteins were eluted with the same buffer at $20 \mathrm{ml} / \mathrm{h}$ and $5 \mathrm{ml}$ fractions were collected. Radioactivity and protein, estimated by absorbance at $280 \mathrm{~nm}$, were measured in all fractions. Fractions containing the bulk of radioactivity were pooled and concentrated to approximately 1 $\mathrm{mg} / \mathrm{ml}$ by dialysis against $15 \%$ polyethylene glycol 600 (Hopkin \& Williams) in Tris-glycine buffer $\mathrm{pH} 8.3$ at $4^{\circ} \mathrm{C}$. This preparation of PBG was used in further studies.

To test the binding stability of purified protein, PBG solutions were heated at $60^{\circ} \mathrm{C}$ for 30 min. Plasma was incubated with $0.2 \mathrm{kBq}\left[{ }^{3} \mathrm{H}\right]$ progesterone at $37^{\circ} \mathrm{C}$ for $15 \mathrm{~min}$ and allowed to equilibrate at $4^{\circ} \mathrm{C}$ for $4 \mathrm{~h}$. Unbound progesterone was removed by dextran-coated charcoal and the amount of protein-bound radioactivity in the supernatant was counted as before. 


\section{Electrophoresis}

Reagents for electrophoresis were obtained from B.D.H., Poole, Dorset, U.K. PBG (100 $\mu \mathrm{g})$ labelled with $\left[{ }^{3} \mathrm{H}\right]$ progesterone was tested for purity on $7 \%$ native poly acrylamine gels at $\mathrm{pH} 8.9$ using the method of Davis (1964). After electrophoresis gels were either stained with $0.25 \%$ Coomassie Blue R250 in 50\% methanol and $8 \%$ acetic acid or cut into $2 \mathrm{~mm}$ slices and solubilized overnight in capped scintillation vials in Soluene 350 (Packard Instrument Co., Cavesham, Berks). Scintillation fluid $(5 \mathrm{ml})$ was added and radioactivity in each slice was measured. Unpurified PBPP was treated in a similar way after incubation with $\left[{ }^{3} \mathrm{H}\right]-$ progesterone. Control gels consisted of the application of $\left[{ }^{3} \mathrm{H}\right]$ progesterone in buffer.

Gel electrophoresis of purified PBG was also carried out using a method in which $0.1 \%$ sodium dodecylsulphate was included in the gels and reservoirs, and purified PBG was previously reduced with mercaptoethanol in the presence of $1 \%$ SDS. This method gave an estimate of molecular weight of PBG when marker proteins (range 21 500-160 000; Boehringer-Mannheim, Lewes, Sussex, U.K.) were run in parallel.

\section{Steroid binding properties of purified $P B G$}

Purified PBG solutions (approx. $0.1 \mathrm{nmol} / \mathrm{ml}$ in phosphate-buffered saline containing $0.1 \%$ gelatin and $0.1 \%$ sodium azide) were incubated overnight at $4^{\circ} \mathrm{C}$ with $0-100 \mathrm{ng}$ of various steroids and $0.2 \mathrm{kBq}\left[{ }^{3} \mathrm{H}\right]$ progesterone. Unbound progesterone was removed using dextrancoated charcoal and the supernatant was decanted into scintillation vials to measure the protein-bound labelled progesterone. Competing efficiency of each steroid compared to that of unlabelled progesterone was calculated by the method of Milgrom et al. (1973).

\section{Radioimmunoassay of progesterone}

Plasma was extracted by the method described earlier with the addition of $0.1 \mathrm{ml} \mathrm{NaOH}$ $(0.6 \mathrm{~mol} / \mathrm{l})$ to denature PBG (Challis, Heap \& Illingworth, 1971). Progesterone was measured in plasma extracts by radioimmunoassay by the procedure described previously (Heap, Holdsworth, Gadsby, Laing \& Walters, 1976). Two antisera were used: antiserum 549 No. 6 was kindly provided by Dr G. E. Abraham, University of California, Los Angeles, U.S.A., and antiserum BF 465 No. 6 was given by $\mathrm{Dr}$ B. J. Furr. The antisera were raised in ewes immunized against 11-deoxycortisol-21-monohemisuccinate-bovine serum albumin and progesterone-11 $\alpha$ succinyl-bovine serum albumin, respectively, and their specificities have been described by Abraham, Swerdloff, Tulchinsky \& Odell (1971) and Heap et al. (1976) respectively. The assay was validated using guinea-pig plasma and the recovery of a known amount of $\left[{ }^{3} \mathrm{H}\right]$ progesterone was $72.3 \pm 1.3 \%$ (mean \pm s.e.m., $n=4$ ), and the intra- and inter-assay coefficients of variation were $16 \cdot 1$ and $7 \cdot 1(0-200 \mathrm{pg})$. Results were corrected for procedural losses incurred during extraction of progesterone.

\section{Results}

\section{Progesterone binding proteins}

In guinea-pigs the concentrations of PBPP showed a biphasic increase with peak values occurring between Days 20-35 and between Days 50-term (about $8 \mathrm{nmol} / \mathrm{ml}$, Text-fig. 1a). The maximum values in casiragua and cuis were about 7 and $10 \mathrm{nmol} / \mathrm{ml}$, respectively (Text-figs $1 \mathrm{~b}$ and $1 \mathrm{c}$ ). In casiragua the highest values were recorded immediately before parturition, whereas in cuis they were found in mid-gestation and remained high until term. In degu and viscacha (Text-figs $1 \mathrm{~d}$ and $1 \mathrm{e}$ ) the maximum values were about 3 and $4 \mathrm{nmol} / \mathrm{ml}$, respectively, and they remained at these values during the second half of gestation. 
Values (nmol/l) in samples taken within 5 days after parturition had decreased or were not detectable (guinea-pig, $5.7(n=2)$; casiragua, $0.6(n=4)$; cuis; $0(n=1)$; viscacha, $1.5(n=5)$.
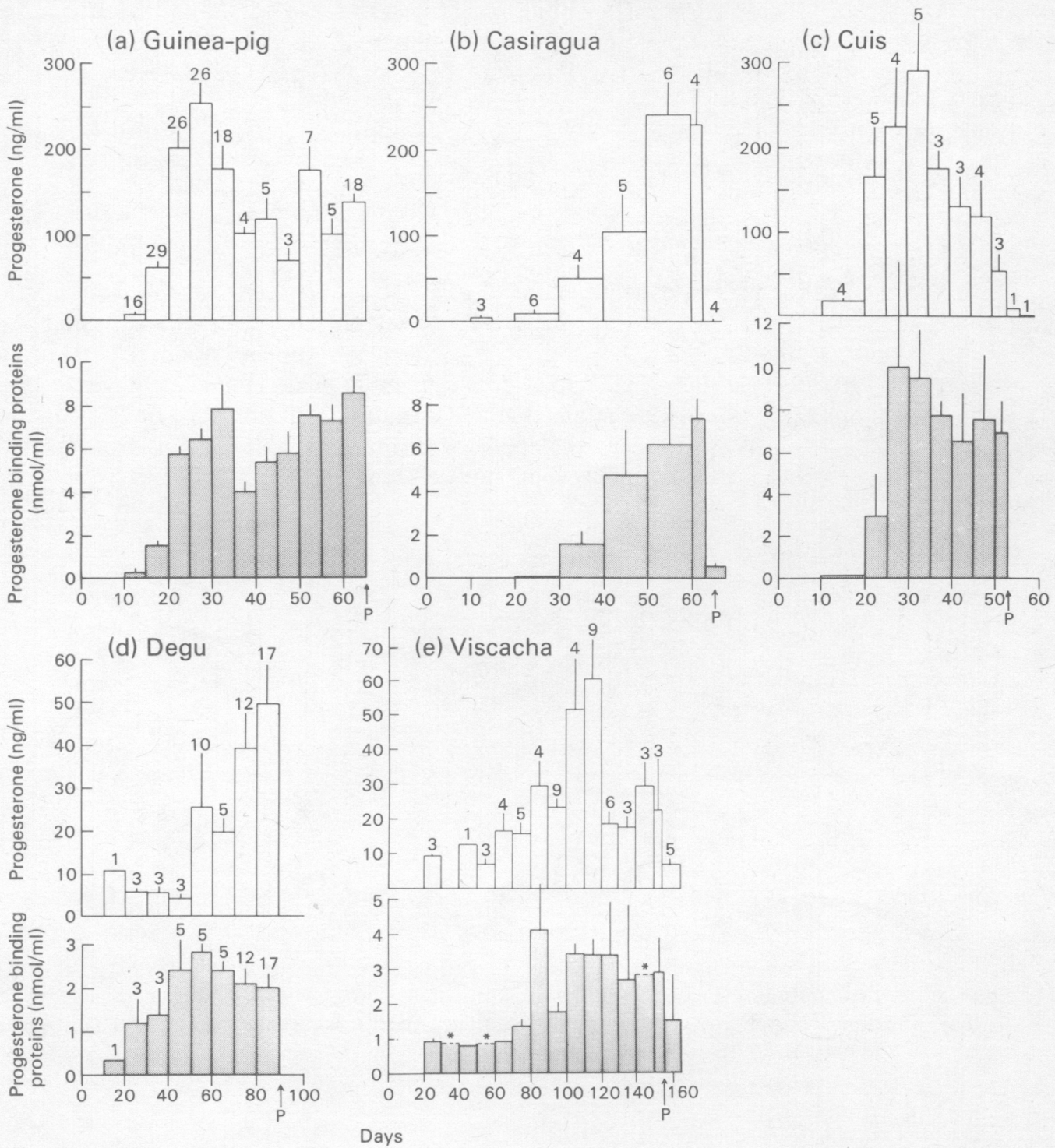

Text-fig. 1. Plasma concentrations of progesterone (open columns) and high affinity progesterone-binding proteins (shaded columns) during gestation in (a) guinea-pig, (b) casiragua, (c) cuis, (d) degu and (e) viscacha. Values are given as mean \pm s.e.m. and number of animals is indicated above each column. * Values estimated because samples were not available. $\mathrm{P}=$ parturition.

\section{Plasma progesterone concentration}

In pregnant guinea-pigs concentrations increased sharply after Day 15 p.c. to reach maximum values between Days 20 and 35 (about $200 \mathrm{ng} / \mathrm{ml}$ ), declining between Days 35 and 50 (about $100 \mathrm{ng} / \mathrm{ml}$ ), but increasing slightly towards the end of gestation (Text-fig. 1a). A different pattern was observed in the other hystricomorphs studied. In casiragua there was a 
gradual increase in concentration throughout gestation with peak values (about $250 \mathrm{ng} / \mathrm{ml}$ ) between Days 50 and 62 (Text-fig. 1b). In cuis the concentration was highest in mid-gestation between Days 25 and 35 (about $250 \mathrm{ng} / \mathrm{ml}$, Text-fig. 1c). In degu and viscacha the maximum concentration was considerably lower $(50-60 \mathrm{ng} / \mathrm{ml}$, Text-figs $1 \mathrm{~d}$ and $1 \mathrm{e})$ than that found in the other species studied. In degu the pattern was similar to that found in casiragua, with maximum values occurring in late pregnancy (Days 80-85); in viscacha peak values were recorded relatively earlier in gestation, between Days 100 and 120.

Values $(\mathrm{ng} / \mathrm{ml}$ ) in samples taken within 5 days after parturition were low (guinea-pig, 45 $(n=2)$; casiragua, $1.5(n=4)$; cuis, $7 \cdot 4(n=1)$; viscacha, $22.3(n=5)$.

\section{Ratio of PBPP to progesterone in plasma}

The molar ratio of the plasma concentrations of PBPP to progesterone exceeded unity in all species studied during gestation (Text-fig. 2). In the guinea-pig and casiragua the ratio was similar throughout gestation (13.9 \pm 1.9 and $14.7 \pm 4.2$, mean \pm s.e.m. of all values). In the cuis it increased progressively during pregnancy to a maximum value immediately before term (41.6). In the degu highest values were attained in mid-gestation with a mean value throughout gestation of $54.2 \pm 19 \cdot 3$. In the viscacha the results were more variable, ranging from 0.52 to $56 \cdot 2$ (mean, $28.5 \pm 4.5$ ) and a clear pattern could not be discerned.

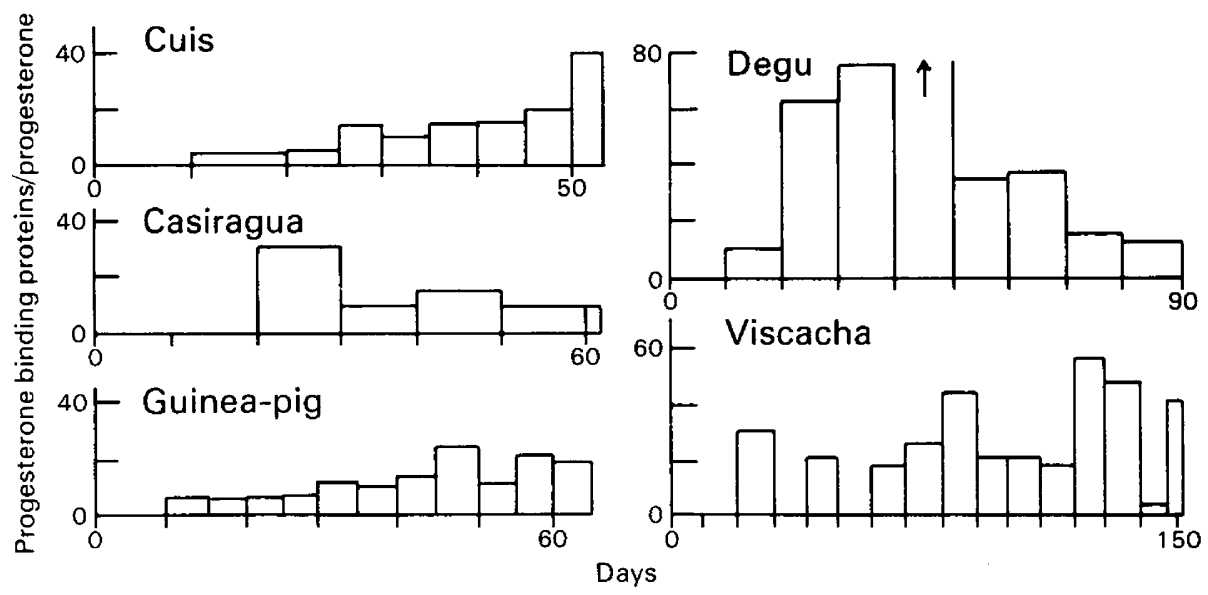

Text-fig. 2. Ratio of plasma concentration of high-affinity progesterone-binding proteins to progesterone during gestation (scaled) in 5 hystricomorph species. In degu, arrow at 40-50 days of gestation indicates a value of 175 .

\section{Purification of $P B G$}

Purification of plasma obtained during pregnancy resulted in a peak of protein labelled with $\left[{ }^{3} \mathrm{H}\right]$ progesterone which eluted ahead of the bulk of other plasma proteins in all 5 species studied (Text-fig. 3). The appropriate fractions were concentrated and the purity of PBG determined by disc gel electrophoresis. The native or SDS-reduced protein from guinea-pigs produced two distinct bands (PBG I and II) stained by Coomassie Blue. Purified PBG from the other hystricomorphs stained as a single broad band (Text-figs 4 and 5). After gel electrophoresis of purified PBG the protein band remained labelled with $\left[{ }^{3} \mathrm{H}\right]$ progesterone added at outset of purification. Profiles of $\left[{ }^{3} \mathrm{H}\right]$ progesterone binding were only slightly affected by heating at $60^{\circ} \mathrm{C}$ for $30 \mathrm{~min}$ before electrophoresis (Text-fig. 4). When the experiment was repeated on unpurified PBG (pregnancy plasma cuis) the heat-stability of the high-affinity binding protein was confirmed (Text-fig. 4). 

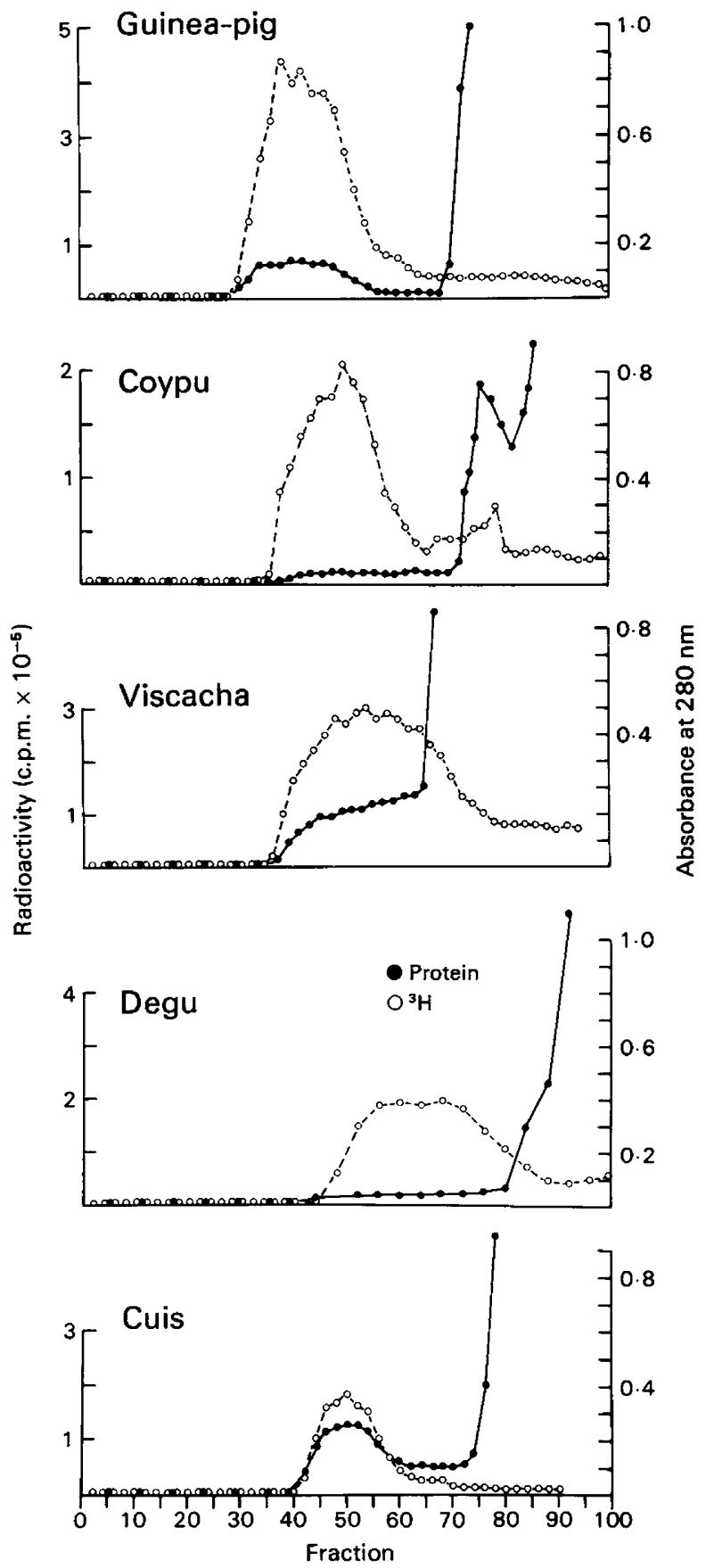

Text-fig. 3. Purification of progesterone binding globulin. Plasma proteins of 5 hystricomorph species were separated on SP-Sephadex C-50 equilibrated with $10 \mathrm{mmol} / 1$ acetate buffer, $\mathrm{pH} 4.5$ at $4{ }^{\circ} \mathrm{C}$. Plasma from pregnant animals was equilibrated with $\left[{ }^{3} \mathrm{H}\right]$ progesterone, applied to the column and $5 \mathrm{ml}$ fractions were collected. Profiles of eluted proteins (closed circles) were monitored by estimation of optical density at $280 \mathrm{~nm}$, and of labelled progesterone (open circles) by measurement of radioactivity. In all five species a protein peak labelled with $\left[{ }^{3} \mathrm{H}\right]$ progesterone was eluted ahead of the bulk of other plasma proteins. 

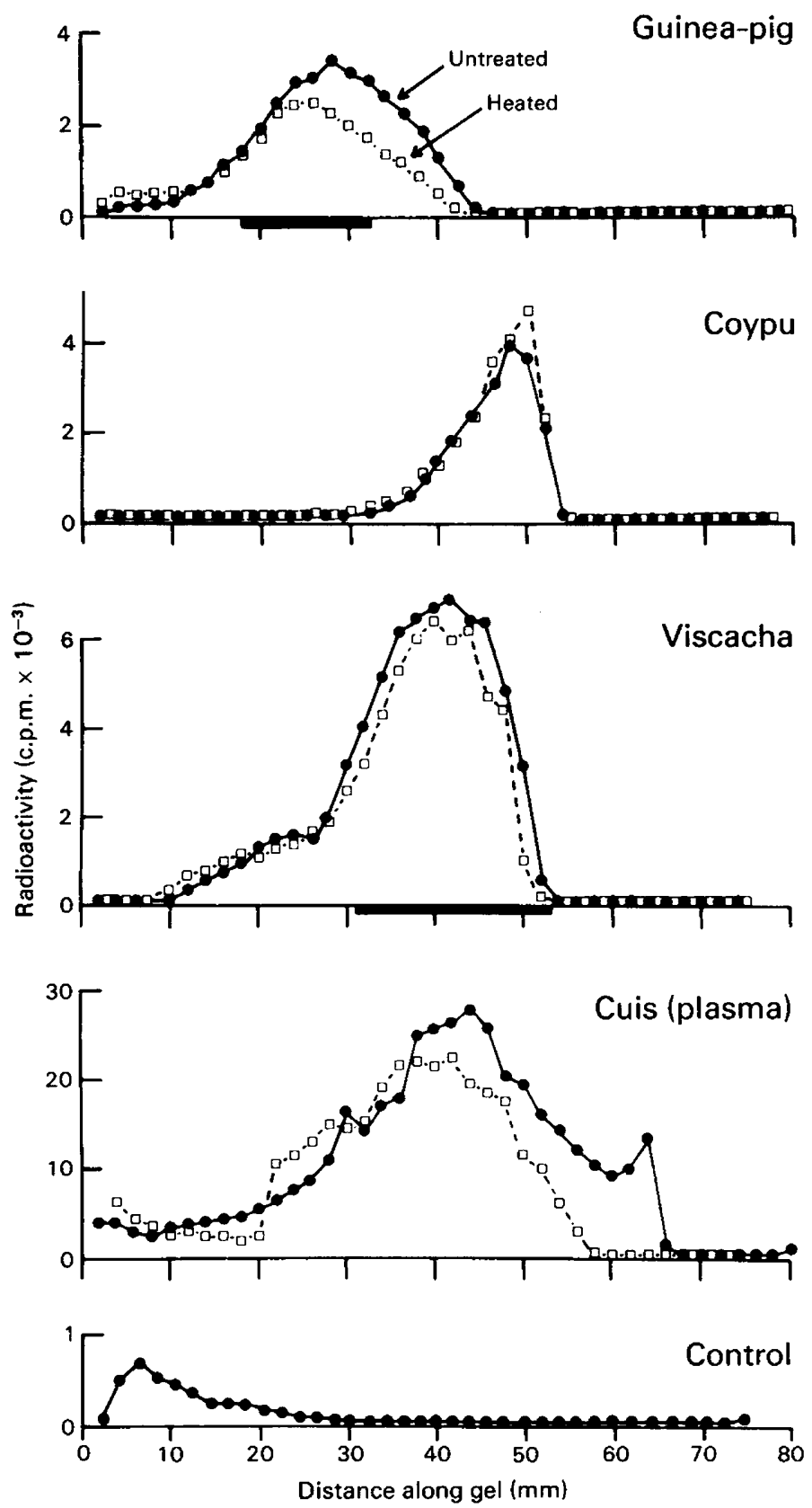

Text-fig. 4. Gel electrophoresis of progesterone binding globulin (PBG) purified on SPSephadex (guinea-pig, coypu and viscacha) and of plasma obtained during pregnancy (cuis). PBG or plasma was equilibrated with $\left[{ }^{3} \mathrm{H}\right]$ progesterone and applied to $7 \%$ polyacrylamide gels at $\mathrm{pH} 8.9$ (see text for method). After electrophoresis gels were stained with Coomassie Blue to localize protein (horizontal black bar) and then sliced into $2-\mathrm{mm}$ bands and counted by scintillation spectrometry to localize $\left[{ }^{3} \mathrm{H}\right]$ progesterone. Binding of labelled progesterone after PBG or plasma was heated at $60^{\circ} \mathrm{C}$ for $30 \mathrm{~min}$ (open squares) was only slightly reduced in guinea-pig and cuis compared to that of untreated PBG or plasma (closed circles). Localization of $\left[{ }^{3} \mathbf{H}\right]$ progesterone added directly to a gel in the absence of protein, or after equilibration with plasma from a non-pregnant guinea-pig is shown in the bottom graph. 


\section{Properties of purified $P B G$}

Molecular weights. The average molecular weights of the PBG proteins measured by gel electrophoresis under denaturing conditions were similar for guinea-pig (PBG I), cuis, degu and viscacha (135000-145000). Coypu PBG had a molecular weight of 75000 and guinea-pig PBG II was 190000 (Text-fig. 5).
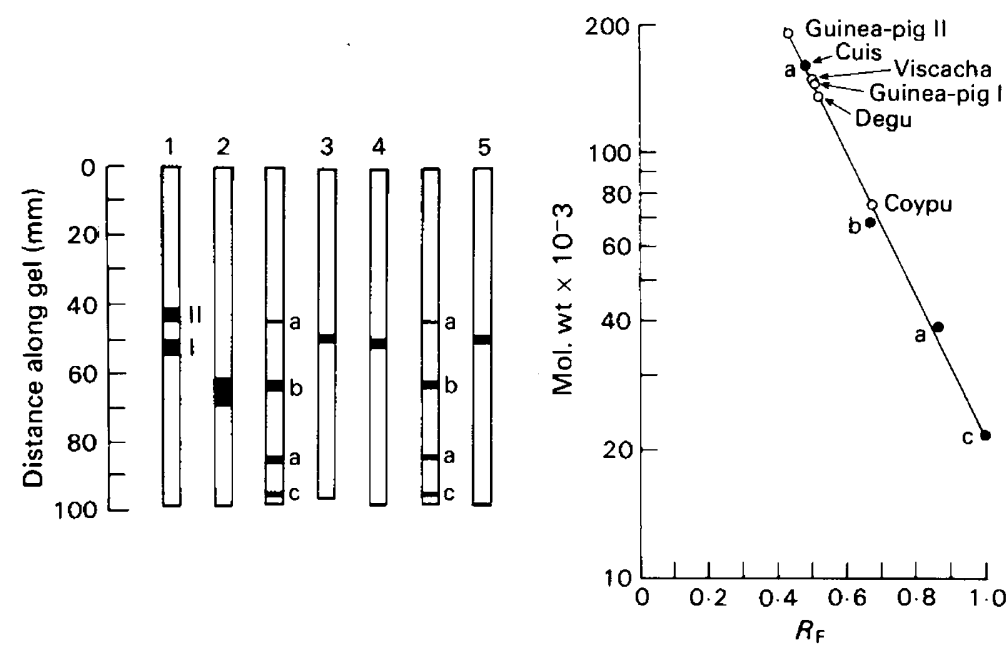

Text-fig. 5. Molecular weight estimations of progesterone-binding globulin (PBG) purified by SP-Sephadex chromatography from plasma of guinea-pig, coypu, cuis, degu and viscacha. PBG reduced with mercaptoethanol in the presence of $1 \%$ sodium dodecyl sulphate (SDS) was applied to $7 \%$ polyacrylamide gels containing $0.1 \%$ SDS. (A) Calibration of gels with molecular weight markers, (a) RNA polymerase (39000 and 160000$)$, (b) bovine serum albumin $(68000)$, and (c) trypsin (21 500). (B) Mobility of PBG after gel electrophoresis and localization with Coomassie Blue stain. Gels were run at $54 \mathrm{~mA}$ and 200 volts for $2.5 \mathrm{~h} ; 1$, guinea-pig I and II; 2 , coypu; 3 , viscacha; 4 , degu; 5 , cuis.

Progesterone binding. Purified PBG was prepared from pooled plasma samples collected in mid-pregnancy from guinea-pig, casiragua, coypu, cuis, degu and viscacha. The average electrophoretic values differed between species being highest for casiragua PBG and lowest for guineapig PBG (Table 1). The values for the binding capacity for purified PBG ranged from 0.5 to $4.8 \times 10^{-6} \mathrm{M}$ and they were similar to those obtained for unpurified PBG, 0.8 to $3.2 \times 10^{-6} \mathrm{M}$. The association constants of purified PBG ranged from 7.6 to $17.4 \times 10^{8} \mathrm{M}^{-1}$ (Table 1).

Table 1. Physico-chemical propertiēs of purified progesterone-binding globulin (PBG) of various hystricomorph rodents

\begin{tabular}{lcccc}
\hline Species & $\begin{array}{c}\text { Gel electrophoresis } \\
\boldsymbol{R}_{\mathbf{F}} \text { value } \dagger\end{array}$ & $\begin{array}{c}\text { Binding capacity } \\
\left(\times 10^{-6} \mathrm{M}\right)\end{array}$ & \multicolumn{2}{c}{$\begin{array}{c}\text { Association constant } \\
\left(\times 10^{8} \mathrm{M}^{-1}\right)\end{array}$} \\
\hline Guinea-pig & $0.30 \pm 0.01(8)$ & 2.7 & Purified & Plasma \\
Casiragua & $0.69 \pm 0.01(3)$ & $7.9 \dagger$ & 17.4 & 16.3 \\
Coypu & $0.59 \pm 0.02(5)$ & 4.8 & n.d. & 32.7 \\
Cuis & $0.55 \pm 0.01(3)$ & 2.0 & 7.6 & 12.0 \\
Degu & $0.34 \pm 0.03(3)$ & $5.0 \dagger$ & 16.7 & 3.4 \\
Viscacha & $0.61 \pm 0.02(7)$ & 0.5 & 10.5 & 10.7 \\
\hline
\end{tabular}

* Values are mean \pm s.e.m. for the no. of determinations in parentheses. $R_{\mathrm{F}}$ value calculated as electrophoretic mobility of PBG relative to tracker dye (1.0).

$†$ Native protein run on $7 \%$ polyacrylamide gel electrophoresis, $\mathrm{pH} 8.9$.

$\ddagger$ Values obtained for PBG in plasma before purification (from Heap \& Illingworth, 1974). 
Specificity of binding. The binding specificities of purified PBG from guinea-pig, coypu, viscacha and cuis differed when tested in a competitive binding assay (Table 2). The competing efficiencies of 5 $\alpha$-pregnane-3,20-dione, 20 $\alpha$-hydroxy-4-pregn-3-one and deoxycorticosterone, from coypu, viscacha and cuis PBG were similar to those for guinea-pig PBG, but the values for other steroids differed markedly between the 4 species. For example, the competing efficiency of $5 \alpha$-dihydrotestosterone was $41 \%$ for guinea-pig PBG, but zero for cuis; that of $20 \beta$ hydroxy-4-pregn-3-one was $25 \%$ for guinea-pig PBG, $77 \%$ for coypu, but only $7 \%$ for cuis. Striking differences were demonstrated between the optical isomers, 20a-hydroxy-4-pregn-3-one and 20 -hydroxy-4-pregn-3-one; the values were 88 and $25 \%$ for guinea-pig, 108 and $77 \%$ for coypu, 101 and $49 \%$ for viscacha and 63 and $7 \%$ for cuis. However, for the $\alpha$ - and $\beta$-isomers of 5 -pregnanedione the differences were less consistent.

Table 2. Ligand specificity of purified progesterone binding globulin in various hystricomorph rodents

\begin{tabular}{|c|c|c|c|c|}
\hline \multirow[b]{2}{*}{ Competing steroid } & \multicolumn{4}{|c|}{ Competing efficiency* with $\left[{ }^{3} \mathrm{H}\right]$ progesterone } \\
\hline & Guinea-pig $\dagger$ & Coypu & Viscacha & Cuis \\
\hline Progesterone & 100 & 100 & 100 & 100 \\
\hline 5a-Pregnane-3,20-dione & $91(97)$ & 84 & 61 & 99 \\
\hline $20 a-H y d r o x y-4-p r e g n-3-o n e$ & $88(90)$ & 108 & 101 & 63 \\
\hline Deoxycorticosterone & $72(86)$ & 100 & 63 & 78 \\
\hline $5 \beta$-Pregnane-3,20-dione & $41(32)$ & 97 & 96 & 84 \\
\hline 5a-Androstan-3-one-17 $\beta$-ol & $41(69)$ & 43 & 36 & \\
\hline Pregnenolone & $32(33)$ & 7 & 9 & \\
\hline Testosterone & $30(40)$ & 35 & 41 & \\
\hline 4-Androstene-3,17-dione & 25 & 28 & 38 & \\
\hline 20ß-Hydroxy-4-pregn-3-one & $25(14)$ & 77 & 49 & \\
\hline 17a-Hydroxyprogesterone & $19(11)$ & 39 & 34 & 34 \\
\hline Cortisol & $12(0)$ & 0 & 7 & \\
\hline Oestradiol & $2(0)$ & 9 & 1 & \\
\hline
\end{tabular}

* Competing efficiency $=\frac{(B) \text { with }\left[{ }^{3} \mathrm{H}\right] \mathrm{P} \text { alone }-(B) \text { with }\left[{ }^{3} \mathrm{H}\right] \mathrm{P}+\text { competing steroid }}{(\mathrm{B}) \text { with }\left[{ }^{3} \mathrm{H}\right] \mathrm{P} \text { alone }-(\mathrm{B}) \text { with }\left[{ }^{3} \mathrm{H}\right] \mathrm{P}+\text { unlabelled } \mathrm{P}} \times 100$

where $B$ is percentage binding.

$\dagger$ Values in parentheses are those of Milgrom et al. (1973).

\section{Discussion}

Comparative studies have demonstrated that PBG was present in maternal plasma during gestation in the hystricomorph rodents studied. The behaviour of purified PBG on SP-Sephadex at low $\mathrm{pH}$ provided evidence that the protein was anionic, a property common to PBG from all the animals investigated and which allowed a single-step isolation of PBG from the majority of other plasma proteins as first described by Stroupe \& Westphal (1975). Purified PBG had a high-affinity for progesterone with an association constant of about $1 \times 10^{9} \mathrm{M}^{-1}$ at $4^{\circ} \mathrm{C}$; a substantial retention of binding after heating at $60^{\circ} \mathrm{C}$ compared with CBG; and showed ligand specificity and protein polydispersity. These features of PBG isolated from various hystricomorph rodents agree in many respects with those previous described for guinea-pig PBG (Burton et al., 1974; Stroupe \& Westphal, 1975; Westphal, Stroupe \& Cheng, 1979).

PBG was detected in all hystricomorph rodents examined, but the temporal pattern of PBPP concentrations in blood and the ligand specificities revealed considerable differences between species. In guinea-pig, plasma PBG levels rose sharply after Day 15, as reported previously (Heap \& Illingworth, 1974). This coincides with the time when the developing allantois establishes close contact with the chorion and the definitive placenta is established. However, it is 
difficult to deduce a causal relation between these events in every species studied since in the casiragua PBPP levels increased only after Day 30, about 10 days after formation of the allantochorionic placenta, while in degu and viscacha they rose at about Day 20, approximately 1-2 weeks before the time of formation of the definitive placenta (Roberts \& Perry, 1975). Clearly the adsorbent technique used in these experiments lacks the sensitivity of an immunochemical method such as that reported by Perrot \& Milgrom (1978). This is exemplified by the immunochemical detection of low concentrations of PBG in fetal plasma (Perrot \& Milgrom, 1978; Millet \& Pasquilini, 1978), in non-pregnant female and in male guinea-pigs (Perrot \& Milgrom, 1978), in contrast to the undetectable values reported hitherto using the adsorbent procedure. Our findings must therefore be interpreted with caution since the adsorbent technique did not detect PBG in the early stages of gestation in any species or in non-pregnant females. We cannot exclude the possibility that enhanced PBG synthesis is associated with formation of the definitive placenta, and that species differences in the time course of PBG levels reflect differences in the rate of PBG synthesis. Knowledge of the factors that regulate PBG synthesis has been hampered by an inability to stimulate PBG synthesis in non-pregnant animals by steroid treatment (Milgrom et al., 1973; Heap \& Illingworth, 1974), as can be achieved for CBG synthesis by oestrogen administration. The failure to stimulate synthesis in the non-pregnant animal is consistent with the idea that the placenta is a major site of synthesis, and this is supported by the immunofluorescence studies of Metz, Micouin \& Chambaz (1977). However, the placenta is clearly not the only source since low levels of PBG have been reported in non-pregnant guinea-pigs (Perrot \& Milgrom, 1978).

The pattern of PBG synthesis in gestation was closely related to that of plasma progesterone concentrations in all species examined. The molar ratio of PBG to progesterone was greater than unity so that the capacity of high-affinity binding frequently exceeded steroid concentration 10 -fold. It is not known whether each molecule of progesterone binding protein contains one binding site for progesterone in all hystricomorph rodents, but in the degu excess binding capacity was particularly marked and the molar ratio reached a value of 175 in mid-gestation and then declined. These findings support the hypothesis advanced for the guinea-pig that PBG production provides a progesterone-conserving mechanism which buffers the effects of rapid steroid metabolism (Illingworth et al., 1973). Westphal et al. (1979) have shown that the high-affinity constant of PBG is related to a high association rate. They have shown that the association $\left(K_{\mathrm{on}}\right)$ and dissociation $\left(K_{\text {off }}\right)$ rate constants for progesterone and PBG are much greater than for any other steroid binding protein in plasma. Such a mechanism provides two requirements of a hormone-transporting protein in blood; (1) rapid dissociation to provide rapid availability, and (2) a fast association to maintain a high circulating concentration in the bound form "for the protection of the organism and of the steroid hormone" (Westphal et al., 1979). It is notable that this progesterone-conserving mechanism has evolved in a suborder of rodents with long gestation periods relative to maternal body weight. In these animals the progesterone requirements of pregnancy seem to be met by a mechanism adopted to ensure a substantial pool of steroid which can dissociate rapidly from its carrier rather than by a marked increase in progesterone production rate (Heap \& Illingworth, 1974). The function of PBG may be to reduce the concentration of freely available progesterone in blood, and to provide a source of progesterone for those binding components such as target cell receptors with a comparable, or even higher affinity constant.

The association constant of SP-Sephadex-purified PBG from guinea-pig plasma measured at $4^{\circ} \mathrm{C}$ by equilibrium dialysis and Scatchard analysis was similar $\left(1.74 \times 10^{9} \mathrm{M}^{-1}\right)$ to values previously published $\left(2.2 \times 10^{9} \mathrm{M}^{-1}\right.$, Westphal et al., 1979;9 $\times 10^{8} \mathrm{M}^{-1}$, Milgrom et al., 1973). Its capacity (about $\left.8 \times 10^{-6} \mathrm{M}\right)$ was also close to other data $\left(13 \times 10^{-6} \mathrm{M}\right.$, Westphal et al., 1979; $16 \times 10^{-6} \mathrm{M}$, Milgrom et al., 1973) and to the direct measurement of PBG by an immunochemical procedure (Perrot \& Milgrom, 1978). This indicates that the values obtained for PBPP throughout gestation relate predominantly to $\mathrm{PBG}$, with a minor contribution from 
CBG. The association constant obtained for PBG from coypu, viscacha and cuis was comparable to that in guinea-pigs, while capacities reached about the same concentration in guinea-pigs, casiragua and cuis, but were lower in degu and viscacha. Ligand specificity of guinea-pig PBG was almost identical to that reported by Milgrom et al. (1973), but there were marked contrasts between different hystricomorph rodents. Lea $(1973 \mathrm{a}, \mathrm{b})$ found that the introduction of hydroxyl groups into the progesterone molecule resulted in a decreased binding affinity of PBG which was proportional to the number of hydroxyl groups involved. The present results show, however, that the polarity rule (Westphal, 1971) does not completely explain PBG-ligand interactions and that the positional effects of introducing a single hydroxyl group are substantial. An hydroxyl group introduced at C-21 and 2 hydrogen atoms at C-20 $\alpha$ produced negligible or small reduction in PBG binding (irrespective of the source of PBG), whereas C-17 $\alpha$ hydroxylation greatly diminished ligand binding by PBG in the four species studied, Moreover, saturation of ring $A$ of the steroid nucleus ( $5 \alpha$ - and $5 \beta$-pregnanedione) gave only small reductions in PBG binding, irrespective of species except for the guinea-pig in which PBG binding of $5 \beta$-pregnanedione (but not of $5 \alpha$-pregnanedione) was reduced by over one-half. These results imply that the spectrum of PBG-ligand specificities varies considerably between different hystricomorph rodents, and that only limited homologies exist.

Polydispersity of guinea-pig PBG is a unique feature among steroid-binding proteins (Westphal et al., 1979). It seems to result from an unusually high carbohydrate content of about $70 \%$ (almost $25 \%$ consisting of sialic acid) attached in different amounts to a polypeptide core of about 27000 molecular weight (Westphal et al., 1979). Polydispersity was observed with SP-Sephadex-purified PBG of guinea-pigs with two broad bands stained by Coomassie Blue on polyacrylamide gel electrophoresis in the presence or absence of SDS, confirming the observations of Burton et al. (1974). SP-Sephadex-purified PBG of the other species also produced a broadly-stained but single band after gel electrophoresis. This was observed with PBG both before and after heating at $60^{\circ} \mathrm{C}$. The PBG also had a high-affinity for progesterone and low binding of cortisol. Apparent molecular weights for guinea-pig PBG I and II in SDS-gel electrophoresis were similar to those found by Burton et al. (1974), but it is well established that glycoproteins give erroneously high molecular weights under these conditions. Subsequent determinations by sedimentation equilibrium ultracentrifugation gave an apparent average molecular weight of 88000 for guinea-pig PBG (PBG I, 117300 ; PBG II, 78 400, Burton et al., 1974). Milgrom et al. (1973) found molecular weights for guinea-pig PBG of 79000 by SDS-polyacrylamide electrophoresis and equilibrium sedimentation, and the absence of a carbohydrate effect in this study remains unexplained. The average molecular weights obtained in our study were 75000 for coypu PBG, but were two-fold greater for guinea-pig (PBG I), cuis, degu and viscacha PBG. Molecules of PBG from the last 3 species did not resolve into two bands, PBG I and II, as found for guinea-pig PBG. Further work is required to determine whether these interspecies differences are related to carbohydrate heterogeneity. However, in view of the restricted homologies discussed above, and the absence of cross-reactivity between rabbit anti-guinea-pig PBG and PBG from the other hystricomorph rodents (Perrot \& Milgrom, 1978), interspecific differences are probably considerable. Should this prove to be so, study of hystricomorph PBG molecules could provide insight into the structure-activity relations of PBG and may throw light on the evolution of this group of mammals. Insulins from New and Old World hystricomorph rodents are also highly divergent; the variation in their sequence is more extensive than that shown between insulins of all other vertebrates and is characteristic of the suborder (Horuk et al., 1979, 1980).

We gratefully acknowledge the contributions of Dr D. V. Illingworth in these studies. 


\section{References}

Abraham, G.F., Swerdloff, R., Tulchinsky, D. \& Odell, N.B. (1971) Radioimmunoassay of plasma progesterone. J. clin. Endocr. Metab. 32, 619-624.

Burton, R.M., Harding, G.B., Rust, N. \& Westphal, U. (1971) Steroid-protein interactions. XXIII. Nonidentity of cortisol-binding globulin and progesterone-binding globulin in guinea-pig serum. Steroids 17, 1-16.

Burton, R.M., Harding, G.B., Aboul-Hosn, W.R., MacLaughlin, D.T. \& Westphal, U. (1974) Progesterone-binding globulin from the serum of pregnant guinea-pigs, a polydisperse glycoprotein. Biochemistry 13, 3554-3561.

Challis, J.R.G., Heap, R.B. \& Illingworth, D.V. (1971) Concentrations of oestrogen and progesterone in the plasma of non-pregnant, pregnant and lactating guinea-pigs. J. Endocr. 51, 333-345.

Davis, B.J. (1964) Disc electrophoresis. II. Method and application to human serum proteins. Ann. N.Y. Acad. Sci. 121, 404-427.

Diamond, M., Rust, N. \& Westphal, U. (1969) Highaffinity binding of progesterone, testosterone and cortisol in normal and androgen-treated guinea-pigs during various reproductive stages: relationship to masculinization. Endocrinology 84, 1143-1151.

Heap, R.B. (1969) The binding of plasma progesterone in pregnancy. J. Reprod. Fert. 18, 546-548.

Heap, R.B. \& Deanesly, R. (1967) The increase in plasma progesterone levels in the pregnant guinea-pig and its possible significance. J. Reprod. Fert. 14, 339-341.

Heap, R.B. \& Illingworth, D.V. (1974) The maintenance of gestation in the guinea-pig and other hystricomorph rodents: changes in the dynamics of progesterone metabolism and the occurrence of progesterone-binding globulin (PBG). Symp. zool. Soc. Lond. 34, 385-415.

Heap, R.B., Holdsworth, R.J., Gadsby, J.E., Laing, J.A. \& Walters, D.E. (1976) Pregnancy diagnosis in the cow from milk progesterone concentration. Br. vet.J. 132, 445-464.

Horuk, R., Goodwin, P., O'Connor, K., Neville, R.W.J., Lazarus, N.R. \& Stone, D. (1979) Evolutionary change in the insulin receptors of hystricomorph rodents. Nature, Lond. 279, 439-440.

Horuk, R., Blundell, T.L., Lazarus, N.R., Neville, R.W.J., Stone, D. \& Wollmer, A. (1980) A monomeric insulin from the porcupine (Hystrix cristata), an Old World hystricomorph. Nature, Lond. 286, 822-824.

Illingworth, D.V., Heap, R.B. \& Perry, J.S. (1970) Changes in the metabolic clearance rate of progesterone in the guinea-pig. J. Endocr. 48, 408-417.

Illingworth, D.V., Ackland, N., Heap, R.B. \& Weir, B.J. (1973) Progesterone binding proteins; occurrence, capacity and binding affinity in hystricomorph rodents. J. Endocr. 58, ii.

Kontula, K., Jänne, O., Rajakoski, E., Tanhuanpää, E. \& Vihko, R. (1974) Ligand specificity of progesterone- binding proteins in guinea-pig and sheep. $J$. Steroid Biochem. 5, 39-44.

Lea, O.A. (1973a) Isolation and characterization of a progesterone- and testosterone-binding globulin from pregnant guinea-pig serum. Biochim. Biophys. Acta 317, 351-363.

Lea, O.A. (1973b) On the steroid specificity of the pregnant guinea-pig progesterone-binding globulin. Biochim. Biophys. Acta 322, 68-74.

Metz, B., Micouin, C. \& Chambaz, E.M. (1977) Origine placentaire de la protéine de liaison de la progestérone chez le Cobaye gravide; étude immunohistologique. C.R. Acad. Sci. Paris 285, 937-940.

Milgrom, E., Atger, M. \& Baulieu, E.-E. (1970) Progesterone binding plasma protein (PBP). Nature, Lond. 228, 1205-1206.

Milgrom, E., Allouch, P., Atger, M. \& Baulieu, E.-E. (1973) Progesterone-binding plasma protein of pregnant guinea-pig. J. biol. Chem. 248, 1106-1114.

Millet, A. \& Pasquilini, J.R. (1978) Liaison specifique de la ${ }^{3} \mathrm{H}$-progestérone à une protéine du plasma du fetus de Cobaye. C.R. Acad. Sci. Paris 287, 1429-1432.

Pegg, P.J. \& Keane, P.M. (1969) The simultaneous estimation of plasma cortisol and transcortin binding characteristics by a competitive protein binding technique. Steroids 14, 705-715.

Perrot, M. \& Milgrom, E. (1978) Immunochemical studies of guinea-pig progesterone-binding plasma protein. Endocrinology 103, 1678-1685.

Roberts, C.M. \& Perry, J.S. (1975) Hystricomorph embryology. Symp. zool. Soc. Lond. 34, 333-358.

Scatchard, G. (1949) The attraction of proteins for small molecules and ions. Ann. N.Y. Acad. Sci. 51, 660-672.

Stroupe, S.D. \& Westphal, U. (1975) Conformational changes in the progesterone binding globulinprogesterone complex. Biochemistry 14, 3296-3300.

Tan, S.Y. \& Murphy, B.E.P. (1974) Specificity of the progesterone-binding globulin of the guinea-pig. Endocrinology 94, 122-127.

Weir, B.J. (1970) The management and breeding of some more hystricomorph rodents. Lab. Anim. 4, 83-97.

Weir, B.J. (1972) Laboratory hystricomorph rodents other than the guinea-pig and chinchilla. In $U F A W$ Handbook on the Care and Management of Laboratory Animals. 4th edn, pp. 278-286. Ed. UFAW. Churchill Livingstone, Edinburgh and London.

Weir, B.J. (1973) Another hystricomorph rodent: keeping casiragua (Proechimys guairae) in captivity. Lab. Anim. 7, 125-134.

Westphal, U. (1971) Steroid-protein interactions. Springer-Verlag, Berlin.

Westphal, U., Stroupe, S.D. \& Cheng, S.-L. (1979) Progesterone binding to serum proteins. Ann. N.Y. Acad. Sci. 286, 10-27.

Received 3 February 1981 